\title{
Genetic variation within and between populations of Posidonia australis, a hydrophilous, clonal seagrass
}

\author{
MICHELLE WAYCOTT* ${ }^{*}$ SIDNEY H. JAMES \& DIANA I. WALKER \\ Department of Botany, The University of Western Australia, Nedlands, 6907, Australia
}

\begin{abstract}
Allozyme diversity was surveyed at 15 loci across 22 populations of the hydrophilous seagrass Posidonia australis (Hook. $f$.). Substantial genetic variation was detected $\left(H_{\mathrm{T}}=0.311\right)$ with a high proportion of this variation partitioned between populations $\left(G_{S T}=0.623\right)$. The high value of $G_{\mathrm{ST}}$ is attributed to large geographical distances between many of the populations and several of the extreme north-western populations having fixed homozygous genotypes. Southwestern populations of $P$. australis were the most variable and these correlate with the highest species diversity in this genus. Intermediate levels of genetic diversity are observed in $P$. australis when compared with other hydrophilous angiosperms. Average gene diversity values for hydrophilous taxa surveyed to date indicate lower $H_{\mathrm{T}}$ and higher $G_{\mathrm{ST}}$ values than an average reported for 468 plant taxa. Patterns of genetic variability in different regions of the distribution of $P$. australis may reflect past evolutionary diversification into novel environments and subsequent dispersal following the rifting of Australia from Antarctica in the early Tertiary.
\end{abstract}

Keywords: allozymes, clonal, evolution, hydrophily, seagrass.

\section{Introduction}

Early population genetic studies on seagrasses and other hydrophilous angiosperms reported a lack of genetic variation and generalized that this was a feature of hydrophiles (McMillan, 1981, 1982, 1991; Wain et al., 1985; Triest, 1991). Recently, a few thorough investigations of genetic variability in hydrophilous angiosperms have demonstrated significant diversity in both the level and distribution of genetic variation. Species such as Ceratophyllum echinatum are predominantly clonal with little variation (Les, 1991), whereas others such as Zostera marina have genetically variable populations comprising many individuals (Laushman, 1993). Several other studies on hydrophiles have investigated the fine-scale genetic structure of populations, documenting both multiclonal (Les, 1991; Laushman, 1993; Alberte et al., 1994; Lokker et al., 1994; Waycott, 1995) and apparently uniclonal (Les, 1991;

*Correspondence and present address: Department of Tropical Environment Studies and Geography, James Cook University, Townsville, QId 4811, Australia. E-mail: michelle.waycott@jcu.edu.au
Waycott et al., 1996) populations. These results emphasize the need for thorough sampling to determine the level and extent of genetic variability within and between populations and to determine population demography and structure.

Posidonia australis (Hook. $f$.) is the broad-leaved form in a complex of three seagrass species ( $P$. australis, $P$. sinuosa and $P$. angustifolia) previously described as 'australis' (Cambridge \& Kuo, 1979). Posidonia australis is widely distributed along the south-western, southern and south-eastern coasts of Australia $\left(25^{\circ} \mathrm{S}, 113^{\circ} \mathrm{E}\right.$ to $\left.31^{\circ} \mathrm{S}, 135^{\circ} \mathrm{E}\right)$ with $P$. sinuosa and $P$. angustifolia being largely sympatric within its range. Posidonia australis is generally considered to be the climax species in sheltered nearshore sandy marine environments throughout its range and is a highly productive, long-lived perennial seagrass. Rhizome extension rates of $P$. australis are slow, of the order of $2.5 \mathrm{~cm} \mathrm{yr}^{-1}$ (West, 1990) and seedling recruitment has not been observed (Kirkman, 1985; Kirkman \& Kuo, 1990). As many regions of $P$. australis and other aquatic macrophytes are being dramatically affected by human impact through physical disturbance and elevated nutrient 
loads (Orth \& Moore, 1983; Cambridge \& McComb, 1984; Walker \& McComb, 1992), increasing attention has been devoted to understanding the ecology and physiology of these organisms.

Knowledge of breeding systems and population genetic structure is necessary to understand the evolutionary processes shaping marine angiosperms and other hydrophiles (Barrett et al., 1993; Waycott \& Les, 1996). However, to date, only one published account of the genetic system of $P$. australis has been undertaken which identified significant within-population genetic variation within a small $\left(400 \mathrm{~m}^{2}\right)$ meadow (Waycott, 1995). In this study we compare the allozymically determined genetic variability present in $P$. australis with other hydrophilous angiosperms and other plant species described in Hamrick \& Godt (1989). The results are also discussed with reference to the process of meadow formation and the possible evolutionary pathways that have led to present-day species distributions in this genus.

\section{Materials and methods}

\section{Collections and sample preparation}

Collections were made from 22 populations of $P$. australis across its geographical range (Fig. 1). Samples were collected at distances greater than those described by Waycott (1995) in a study of genetic variation in a single population, to maximize the collection of different genets. Each collection had between nine and 70 ramets (on average 28 ramets per population) collected at least $5 \mathrm{~m}$ apart and within an area usually $200 \times 200 \mathrm{~m}$ (but this was dependent on the extent of the meadow being sampled). After processing, samples were stored frozen at $-80^{\circ} \mathrm{C}$ for up to 8 months until use.

\section{Allozyme electrophoresis and data analysis}

Horizontal starch gel electrophoresis was conducted according to Waycott (1995) using two buffer

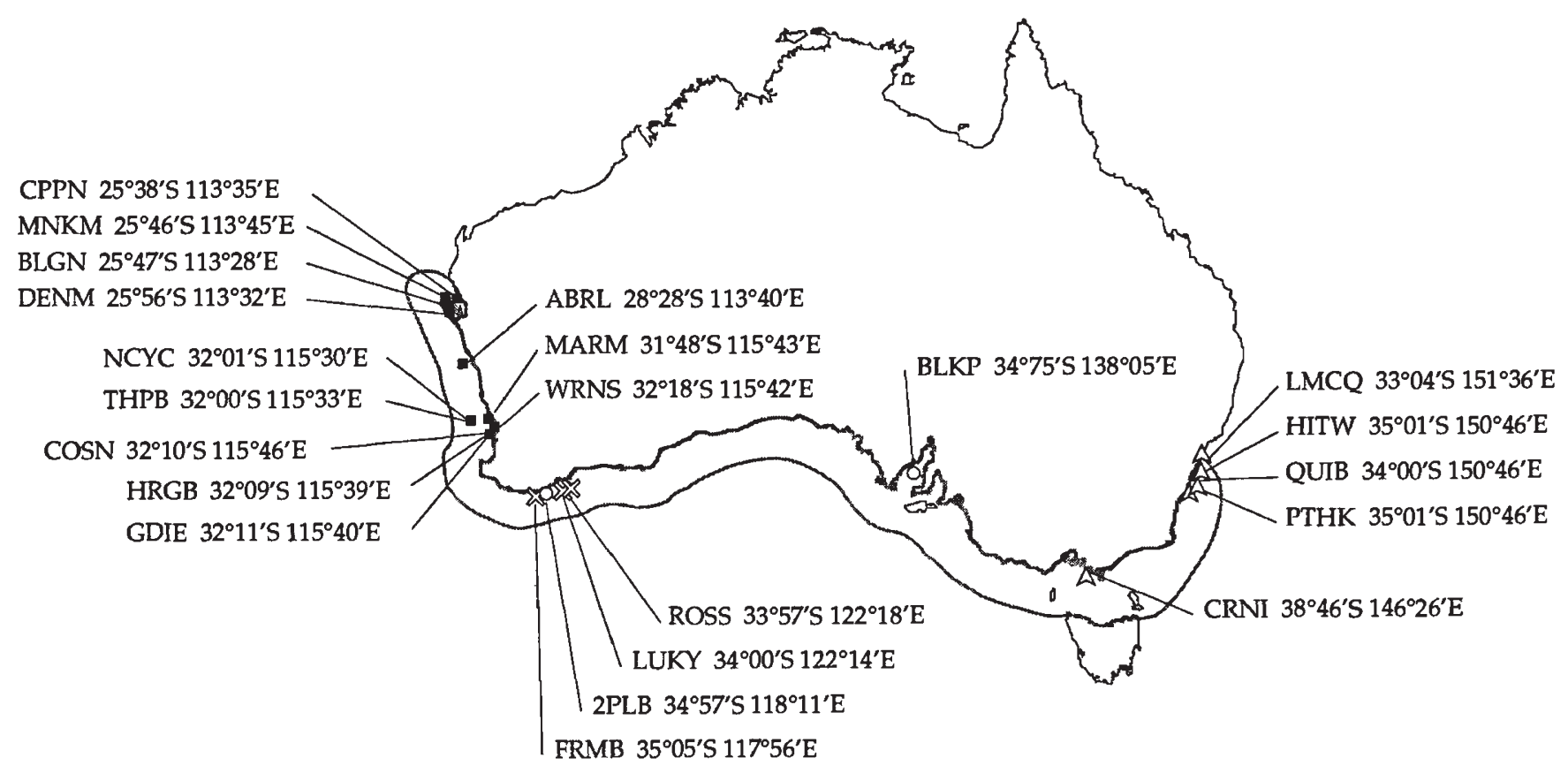

Fig. 1 Distribution of Posidonia australis in nearshore habitats over the range indicated by the outlined region. Population collections were made at the sites indicated with a symbol. Populations are indicated by their population code as follows in parentheses: Big Lagoon, Shark Bay (BLGN); Denham, Shark Bay (DENM); Cape Peron, Shark Bay (CPPN); Monkey Mia, Shark Bay (MNKM); Wallabi Island, Abrolhos (ABRL); Nancy Cove, Rottnest (NCYC); Thompsons Bay, Rottnest (THPB); Herring Bay, Garden Island (HRGB); Sulphur Bay, Garden Island (GDIE); Warnbro Sound, Rockingham (WRNS); Marmion Lagoon, Perth (MARM); Cockburn Sound, Rockingham (COSN); Frenchman Bay, Albany (FRMB); Two People Bay, Albany (2PLB); Lucky Bay, Esperence (LUKY); Rossiter Bay, Esperence (ROSS); Section Bank/Black Pole, Barker Inlet (BLKP); Little Snake Island, Corner Inlet (CRNI); 'Hole in the Wall', Jervis Bay (HITW); Costen's Point, Port Hacking (PTHK); Quibray Bay, Botany Bay (QUIB); Wangi Wangi Point, Lake Macquarie (LMCQ). Symbols on population locations refer to population clusters in Fig. 2. 
systems, scoring a total of 15 loci from nine enzyme systems across all 22 populations (Table 1). Samples from the most polymorphic population, Lucky Bay, were run on all gels for comparative allelic designations.

Population genetic parameters were calculated for all samples as follows: allele frequencies, $P$ (percentage polymorphic loci, 0.99 criterion), $H_{0}$ (observed heterozygosity) and $H_{\mathrm{e}}$ (expected panmictic heterozygosity) were calculated using the computer program Biosys-1 (Swofford \& Selander, 1981); $A_{\mathrm{c}}$ (effective number of alleles per locus) and $P_{\mathrm{s}}$ (total number of polymorphic loci at the species level) were calculated according to Hamrick \& Godt (1989); $M_{1}$ (number of multilocus genotypes) was calculated as the total number of different multilocus genotypes present in all the ramets sampled in each population. The multilocus genotype diversity statistic, $D_{\mathrm{G}}$, which reflects the relative frequency of specific genotypes within the sampled pool of ramets, was calculated in the manner of Ellstrand \& Roose (1987). A $D_{\mathrm{G}}$ value of one indicates all ramets have a unique multilocus genotype, whereas a value of zero indicates all ramets have a common multilocus genotype. The allelic diversity statistics of Nei (1978), $H_{\mathrm{S}}, H_{\mathrm{T}}, D_{\mathrm{ST}}$ and $G_{\mathrm{ST}}$ (for polymorphic loci) and UPGMA cluster analysis with standard errors were calculated using the computer programs, GD and GDD, of Ritland (1989), which calculate $D_{\mathrm{ST}}$ and $G_{\mathrm{ST}}$ from mean $H_{\mathrm{T}}$ and $H_{\mathrm{S}}$ values for species totals and individual polymorphic loci.

\section{Results}

A total of 634 samples was analysed from 22 populations; 15 loci were scored across all populations. Five loci were polymorphic, but the number of polymorphic loci per population varied from four in two populations (BLKP, MARM) to zero in six populations (GDIE, ABRL, BLGN, MNKM, CPPN, DENM) (Table 2).

The average number of detectable multilocus genotypes per population was 4.6 , with a wide range from one genotype per population $\left(D_{\mathrm{G}}=0\right)$ in eight populations to 19 multilocus genotypes identified in the LUKY population. In the LUKY population 73 per cent of the ramets had identifiably different genotypes. $D_{\mathrm{G}}$ values in three populations, ROSS, LUKY and MARM, were greater than 0.9, indicating many different genets without predominance of any one within the population (Table 3 ).

Allele frequencies of polymorphic loci are shown for all populations in Table 2. The maximum number of alleles per locus was four $(P G M-1)$. The mean effective number of alleles per locus $\left(A_{\mathrm{e}}\right)$ was 1.07 and ranged from 1 to 1.26 (Table 3 ). The mean proportion of polymorphic loci per population $(P)$ was 11 per cent, although the proportion of polymorphic loci for the species $\left(P_{\mathrm{s}}\right)$ was 33 per cent because some loci were polymorphic between populations. The average observed heterozygosity $\left(H_{\mathrm{o}}\right)$ was 0.045 and the expected panmictic heterozygosity $\left(H_{\mathrm{e}}\right)$ was 0.039 . However, values ranged from zero in the genotypically uniform populations to $H_{\mathrm{o}}=0.131$

Table 1 Enzyme systems examined, the buffer systems used and the loci scored and observed (in parentheses). Starch buffer systems (MC, morpholine citrate; Moran \& Hopper, 1983) run at $60 \mathrm{~mA}$ for $4.5 \mathrm{~h}$; SAC/TC, Tris citrate modified (S. Carstairs, personal communication [100 $\mathrm{mm}$ Tris, $30 \mathrm{~mm}$ citric acid, $6.4 \mathrm{~mm}$ histidine (free base), $13 \mathrm{~mm}$ glycine, $5 \mathrm{~mm}$ $\mathrm{Na}_{2}$ EDTA, $2.5 \mathrm{~mm} \mathrm{MgCl}_{2}$, buffer to $\mathrm{pH} 7.4$ with $\left.\mathrm{NaOH}\right]$ ) run at $65 \mathrm{~mA}$ for $5 \mathrm{~h}$

\begin{tabular}{lllll}
\hline Enzyme & Abbreviation & EC code & Buffer system & $\begin{array}{l}\text { Loci scored } \\
\text { (Loci observed) }\end{array}$ \\
\hline$\alpha$-Acid phosphatase & AAP & 3.1 .3 .2 & SAC/TC & $1(1)$ \\
Diaphorase & DIA & 1.8 .1 .4 & SAC/TC & $-(2)$ \\
Fluorescent esterase & EST & $3.1 .1 .-$ & SAC/TC & $1(1)$ \\
Glucose phosphate isomerase & GPI & 5.3 .1 .9 & SAC/TC & $2(2)$ \\
Isocitrate dehydrogenase & IDH & 1.1 .1 .42 & SAC/TC & $1(1)$ \\
Malate dehydrogenase & MDH & 1.1 .1 .37 & MC & $4(4)$ \\
Malic enzyme & MEN & 1.1 .1 .40 & MC & $1(1)$ \\
Menadione reductase & MR & $1.6 .99 .-$ & SAC/TC & $-(1)$ \\
Peroxidase & PER & 1.11 .1 .7 & MC & $1(3)$ \\
Phosphoglucomutase & PGM & 5.4 .2 .2 & SAC/TC & $2(3)$ \\
Phosphogluconate dehydrogenase & PGD & 1.1 .1 .44 & MC & $1(2)$ \\
Shikimic acid dehydrogenase & SDH & 1.1 .1 .25 & MC & $1(1)$ \\
\hline
\end{tabular}




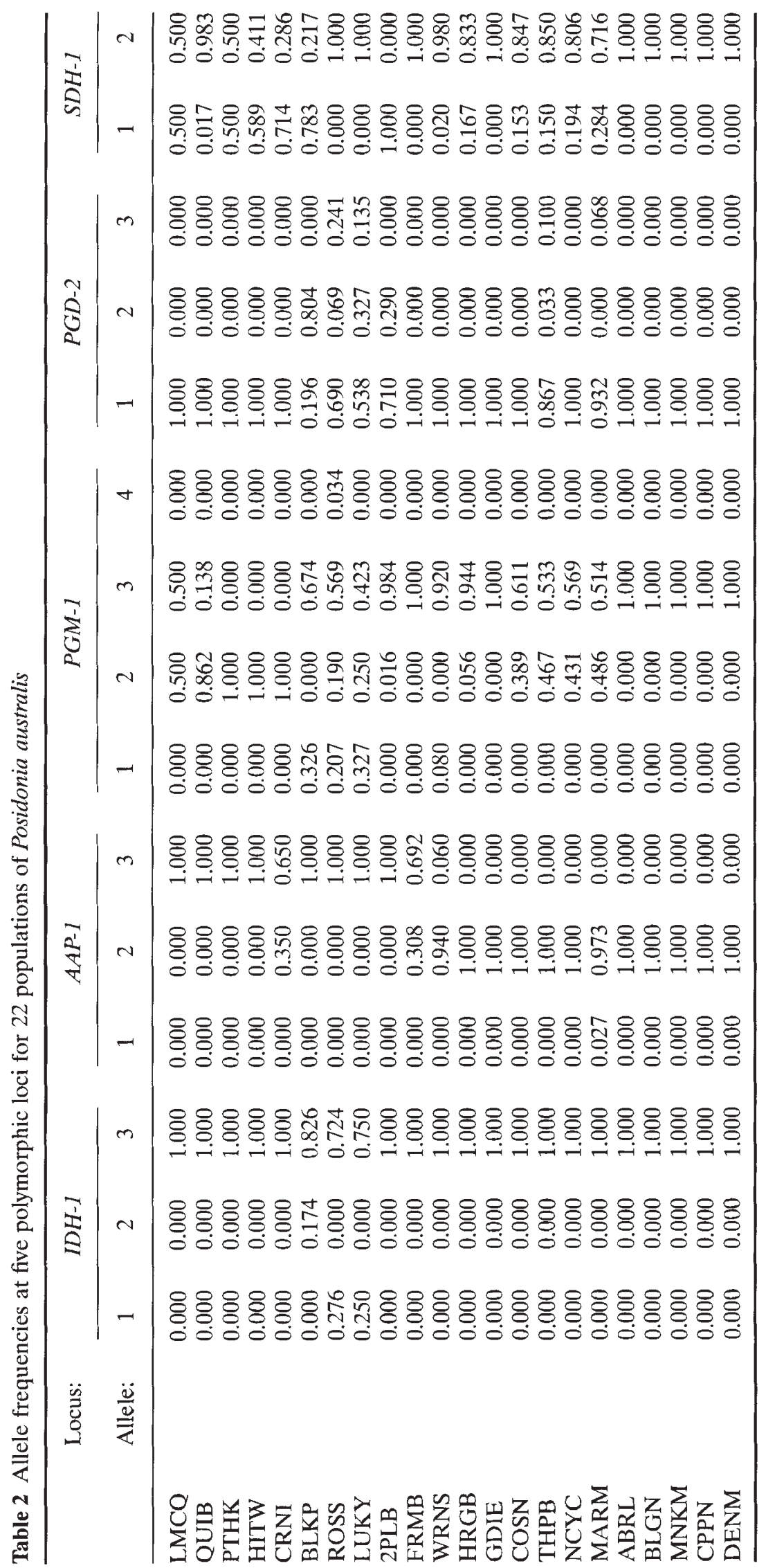


and $H_{\mathrm{e}}=0.110$ in LUKY, the most genotypically diverse population (Table 3 ). The average values were different from those calculated for 468 species presented by Hamrick \& Godt (1989), of $A_{\mathrm{e}}=1.15$ and $H_{\mathrm{e}}=0.113$. Fixation was observed at some loci in some populations (Table 4) but significant deviations of $F$ from zero occurred in only five out of a possible 36 cases (14 per cent). These loci were either fixed as observed in the two polymorphic loci $P G M-1$ and $S D H-1$ in LMCQ or represented a complete lack of heterozygotes within polymorphic populations such as $A A P-1$ in FRMB. Overall there was a mix of positive and negative $F$-values (Table 4). The six populations which were completely monomorphic all had the same multilocus genotype (Table 2).

Genetic diversity statistics calculated for individual polymorphic loci and as a mean for all polymorphic loci (Table 5) demonstrate a high $G_{\mathrm{ST}}$, indicating that, on average, 62.3 per cent of the diversity was between populations. The high $G_{\mathrm{ST}}$ value for the $A A P-1$ locus (0.902) is attributable to the fixation of alleles 2 and 3 in different populations (see Table 2). The mean $G_{\mathrm{ST}}$ for all polymorphic loci is 0.494 if $A A P-1$ is excluded. The mean $H_{\mathrm{T}}$ is 0.311 , ranging from 0.063 at $I D H-1$ to 0.491 at AAP-1.

The maximum genetic distance between populations was 0.116 and UPGMA analysis demonstrated a general geographical trend from the eastern to southern to western populations (Fig. 2). Three significant clusters of populations occur. The western populations form one group and two different clusters of eastern and southern populations another group (Fig. 2). The trend generally follows a geographical gradient with more closely located populations clustering with each other rather than with those farther away. The western group of populations reflects the high level of genetic similarity, particularly the occurrence of identical homozygous allozyme genotypes in the Shark Bay populations (DENM, CPPN, MNKM, BLGN), the island population from the Abrolhos Islands (ABRL) and one Garden Island population (GDIE).

Table 3 Genetic diversity within populations of Posidonia australis

\begin{tabular}{|c|c|c|c|c|c|c|c|}
\hline Population & $n$ & $P$ & $A_{\mathrm{e}}$ & $H_{\mathrm{o}}$ & $H_{\mathrm{e}}$ & $M_{1}$ & $D_{\mathrm{G}}$ \\
\hline LMCQ & 30 & 13.3 & 1.13 & $0.133(0.091)$ & $0.068(0.046)$ & 1 & 0.000 \\
\hline QUIB & 29 & 13.3 & 1.02 & $0.021(0.018)$ & $0.018(0.016)$ & 3 & 0.431 \\
\hline РТНK & 29 & 6.7 & 1.07 & $0.067(0.067)$ & $0.034(0.034)$ & 1 & 0.000 \\
\hline HITW & 28 & 6.7 & 1.06 & $0.055(0.055)$ & $0.033(0.033)$ & 2 & 0.304 \\
\hline CRNI & 70 & 13.3 & 1.10 & $0.062(0.044)$ & $0.058(0.040)$ & 8 & 0.815 \\
\hline BLKP & 23 & 26.7 & 1.14 & $0.099(0.054)$ & $0.094(0.043)$ & 4 & 0.688 \\
\hline ROSS & 29 & 20.0 & 1.19 & $0.110(0.060)$ & $0.099(0.054)$ & 13 & 0.924 \\
\hline LUKY & 26 & 20.0 & 1.26 & $0.131(0.073)$ & $0.110(0.060)$ & 19 & 0.969 \\
\hline 2PLB & 31 & 13.3 & 1.05 & $0.037(0.034)$ & $0.030(0.028)$ & 4 & 0.578 \\
\hline FRMB & 26 & 6.7 & 1.05 & $0.000(0.000)$ & $0.029(0.029)$ & 2 & 0.443 \\
\hline WRNS & 25 & 20.0 & 1.02 & $0.021(0.013)$ & $0.020(0.012)$ & 5 & 0.423 \\
\hline HRGB & 9 & 13.3 & 1.03 & $0.030(0.023)$ & $0.027(0.020)$ & 3 & 0.556 \\
\hline GDIE & 9 & 0.0 & 1.00 & $0.000(0.000)$ & $0.000(0.000)$ & 1 & 0.000 \\
\hline COSN & 36 & 13.3 & 1.08 & $0.050(0.035)$ & $0.050(0.035)$ & 4 & 0.729 \\
\hline ТНРВ & 30 & 20.0 & 1.11 & $0.040(0.024)$ & $0.067(0.039)$ & 7 & 0.789 \\
\hline NCYC & 35 & 13.3 & 1.09 & $0.035(0.027)$ & $0.054(0.038)$ & 6 & 0.790 \\
\hline MARM & 37 & 26.7 & 1.13 & $0.061(0.038)$ & $0.073(0.042)$ & 13 & 0.910 \\
\hline ABRL & 35 & 0.0 & 1.00 & $0.000(0.000)$ & $0.000(0.000)$ & 1 & 0.000 \\
\hline BLGN & 12 & 0.0 & 1.00 & $0.000(0.000)$ & $0.000(0.000)$ & 1 & 0.000 \\
\hline MNKM & 35 & 0.0 & 1.00 & $0.000(0.000)$ & $0.000(0.000)$ & 1 & 0.000 \\
\hline CPPN & 9 & 0.0 & 1.00 & $0.000(0.000)$ & $0.000(0.000)$ & 1 & 0.000 \\
\hline DENM & 40 & 0.0 & 1.00 & $0.000(0.000)$ & $0.000(0.000)$ & 1 & 0.000 \\
\hline Average & 28 & $11\left(P_{\mathrm{s}}=33\right)$ & 1.07 & 0.045 & 0.039 & 4.6 & 0.425 \\
\hline
\end{tabular}

$P$, percentage polymorphic loci (frequency $<0.99$ ); $n$, number of ramets sampled; $A_{\mathrm{e}}$, effective number of alleles per locus; $H_{\mathrm{o}}$, observed heterozygosity; $H_{\mathrm{e}}$, expected panmictic heterozygosity; $M_{1}$, number of multilocus genotypes; $D_{\mathrm{G}}$, multilocus genotype diversity; $P_{\mathrm{S}}$, percentage polymorophic loci across all populations; standard errors in parentheses. 
Table 4 Fixation indices $(F)$ for polymorphic loci in each Posidonia australis population surveyed

\begin{tabular}{lccccc}
\hline & \multicolumn{5}{c}{ Locus } \\
\cline { 2 - 6 } Population & PGM-1 & SDH-1 & AAP-1 & IDH-1 & PGD-2 \\
\hline LMCQ & $-1.000^{*}$ & $-1.000^{*}$ & - & - & - \\
QUIB & -0.160 & -0.018 & - & - & - \\
PTHK & - & $-1.000^{*}$ & - & - & - \\
HITW & - & -0.697 & - & - & - \\
CRNI & - & -0.160 & -0.287 & - & - \\
BLKP & -0.484 & -0.278 & - & $1.000^{*}$ & -0.243 \\
ROSS & -0.157 & - & - & -0.208 & -0.046 \\
LUKY & -0.121 & - & - & -0.128 & -0.381 \\
2PLB & -0.016 & - & - & - & -0.253 \\
FRMB & - & - & $1.000^{*}$ & - & - \\
WRNS & -0.087 & -0.020 & -0.064 & - & - \\
HRGB & -0.059 & -0.200 & - & - & - \\
GDIE & - & - & - & - & - \\
COSN & 0.065 & -0.180 & - & - & - \\
THPB & 0.866 & -0.176 & - & - & 0.019 \\
NCYC & 0.717 & -0.241 & - & - & - \\
MARM & 0.459 & -0.263 & - & - & -0.072 \\
ABRL & - & - & - & - & - \\
BLGN & - & - & - & - & - \\
MNKM & - & - & - & - & - \\
CPPN & - & - & - & - & - \\
DENM & - & - & - & - & - \\
\hline
\end{tabular}

*Significant departures from zero for chi-squared tests of $F$-values using Šidák's correction $(P<0.0004)$ (Šidák, 1967).
These populations, plus the other Garden Island population (HRGB) and the Warnbro Sound population (WRNS), share a single most common genotype which clusters them tightly. There is a considerable increase in the number of polymorphic loci and the number of alleles present in the southern and eastern populations which contributes to the higher genetic distances observed between these populations. The populations at the extremes of the range of $P$. australis tend to be more homozygous and genetically uniform.

\section{Discussion}

The proportion of genetic variation between populations $\left(G_{\mathrm{ST}}=0.623\right)$ in $P$. australis compared with the mean for 468 taxa (Hamrick \& Godt, 1989) is high (Table 6). Among the hydrophiles $P$. australis has intermediate levels of genetic diversity (Table 6).

Table 5 Genetic diversity statistics for polymorphic loci of Posidonia australis and total diversity statistics for the species

\begin{tabular}{lcccc}
\hline Locus & $H_{\mathrm{T}}$ & $H_{\mathrm{S}}$ & $D_{\mathrm{ST}}$ & $G_{\mathrm{ST}}$ \\
\hline$I D H-1$ & 0.063 & 0.050 & 0.013 & 0.206 \\
$A A P-1$ & 0.491 & 0.048 & 0.443 & 0.902 \\
$P G M-1$ & 0.481 & 0.217 & 0.264 & 0.549 \\
$P G D-2$ & 0.174 & 0.099 & 0.075 & 0.431 \\
$S D H-1$ & 0.354 & 0.176 & 0.178 & 0.502 \\
Total for species & 0.311 & 0.117 & 0.194 & 0.623 \\
\hline
\end{tabular}

Fig. 2 UPGMA analysis of genetic distance (Nei, 1978) with standard errors (shaded bars), where a significant cluster occurs if the shaded bar is less than half the branch length (Ritland, 1989). Populations in the top cluster form a group from eastern and southern populations, whereas the lower cluster forms a group from western populations (see Fig. 1 for locality details). Symbols for the major statistically significant clusters are provided for reference to localities in Fig. 1.

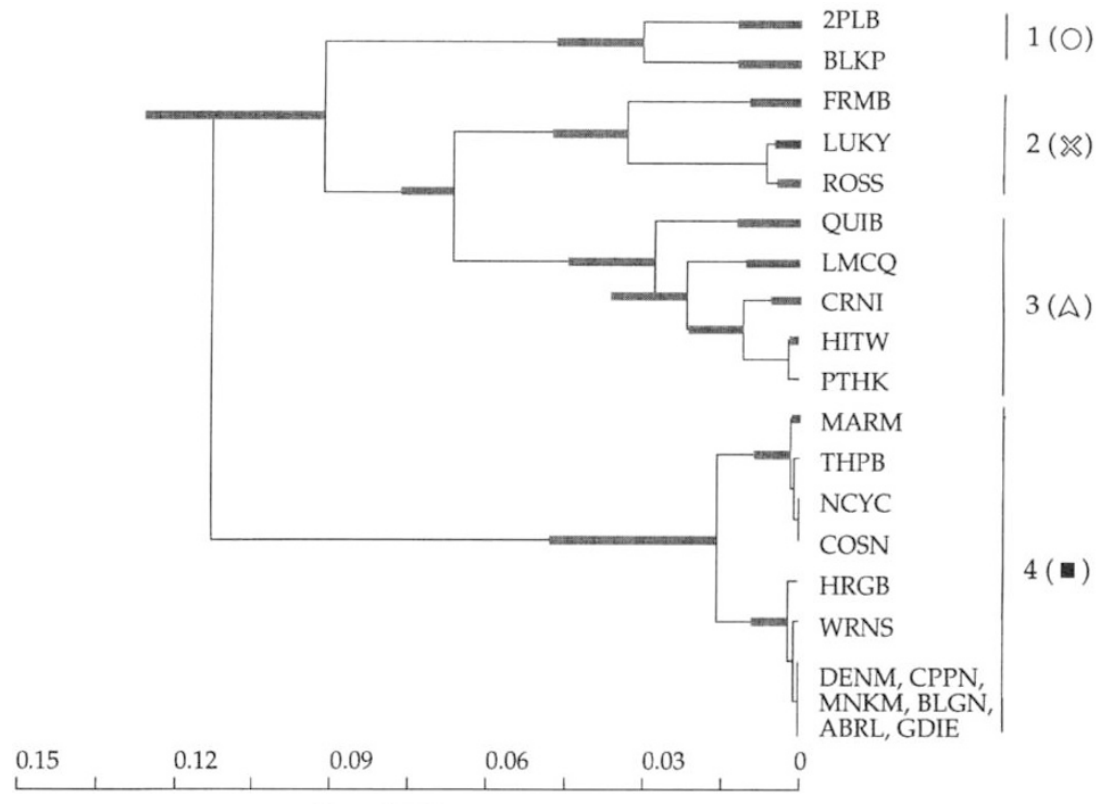

Genetic Distance 
Values for $P$ and $H_{\mathrm{c}}$ are significantly lower in $P$. australis, and are near the average for $H_{\mathrm{T}}$, compared with the categories proposed by Hamrick \& Godt (1989). Low values for $H_{\mathrm{e}}$ and high $G_{\mathrm{ST}}$ in $P$. australis together distinguish this species from most of the proposed categories. The only category with a similar $G_{\mathrm{ST}}$ value is that of a selfing breeding system, although selfing species are usually associated with a higher $H_{\mathrm{c}}(0.149)$ than observed in $P$. australis $(0.039)$. If the summary results are used as predictors of breeding system, then they suggest that $P$. australis has a selfing breeding system. However, although this species has the potential to self-pollinate, being functionally hermaphrodite, concurrent studies have identified high outcrossing rates in several populations (Waycott \& Sampson, 1997).

Equivalent allozyme diversity was not found in eastern and western populations of this species. Some populations, particularly from the northwestern extremes of the range (the Shark Bay populations), have a common, homozygous, multilocus genotype. South-western Australian populations of $P$. australis exhibit considerably more genetic variability, having higher levels of allelic variation, greater number of polymorphic loci, and high $D_{\mathrm{G}}$ values indicating a greater number of genets per population. South-eastern populations are variable in some cases but intermediate to the two westerly regions. UPGMA analysis revealed a trend which is driven by the fixed genotype observed in the homozygous north-western populations and the very widely spaced population collections, whereby large differentiation between populations may be expected.
The occurrence of many populations with a common homozygous multilocus genotype (DENM, CPPN, MNKM, BLGN, ABRL, GDIE) may be interpreted in two ways. First, it may represent the result of a limited founding population (Barrett \& Shore, 1989) from tight genetic bottlenecks during the process of range extension. On the west coast prevailing currents are from north to south and the long-distance movements of short-lived propagules (mature fruit, see Kuo, 1982) are unlikely. This makes dispersal to new, more northerly environments improbable. Thus, a genotypically limited founding population might give rise to a widespread homozygous genotype through inbreeding. The second hypothesis is that these populations are highly clonal. Should this be the case, clones may be very large and extremely old. This hypothesis had been proposed earlier because of the infrequent or zero recruitment and slow recovery of populations following disturbance (Kirkman \& Kuo, 1990). However, it has already been demonstrated that allozymes underestimate the level of variation present in this species (Waycott, 1995) and homozygous populations need not be entirely vegetative. Also, sexual reproduction is common in many of these populations (Walker, 1989), even if recruitment from sexual propagules is rare. In all, the lack of variability is more likely to be caused by founder effects and inbreeding.

Significant variation in the extent and distribution of genetic variation has been demonstrated in studies on a number of terrestrial clonal plant species and may be expected among species with a variety of sexual and asexual reproductive strategies

Table 6 Comparison of genetic diversity with other hydrophilous angiosperms (based on polymorphic loci for species)

\begin{tabular}{|c|c|c|c|c|c|c|}
\hline Species & $\begin{array}{c}\text { No. of } \\
\text { Populations }\end{array}$ & $\begin{array}{l}\text { No. of } \\
\text { Loci }\end{array}$ & $P$ & $H_{\mathrm{c}}$ & $H_{\mathrm{T}}$ & $G_{\mathrm{ST}}$ \\
\hline Posidonia australis $^{1}$ & 22 & 15 & 33.3 & 0.039 & 0.311 & 0.623 \\
\hline Ceratophyllum demersum ${ }^{2}$ & 9 & 17 & 20.0 & 0.064 & 0.211 & 0.495 \\
\hline Ceratophyllum echinatum $^{2}$ & 3 & 17 & 7.0 & 0.036 & 0.529 & 0.481 \\
\hline Zostera marina ${ }^{3}$ & 7 & 24 & 38.5 & 0.085 & - & 0.457 \\
\hline Amphibolis antarctica ${ }^{4}$ & 7 & 14 & 0.0 & 0.000 & 0.000 & - \\
\hline Average for true hydrophiles & 10.25 & 18.25 & 19.76 & 0.045 & $0.26^{*}$ & $0.514 \dagger$ \\
\hline Summary of $468 \operatorname{taxa}^{5}$ & 12.70 & 16.50 & 34.20 & 0.113 & 0.31 & 0.224 \\
\hline
\end{tabular}

${ }^{1}$ This study, ${ }^{2}$ Les(1991), ${ }^{3}$ Laushman (1993), ${ }^{4}$ Waycott et al. (1996), ${ }^{5}$ Hamrick \&

Godt (1989). *Averaged for values reported only.

$\dagger$ Not calculated for $A$. antarctica because $G_{\mathrm{ST}}$ cannot be calculated for this

species as no differentiation was observed. 
(Ellstrand \& Roose, 1987; Murawski \& Hamrick, 1990; Les, 1991; Eckert \& Barrett, 1993). The relative levels of sexual and asexual reproduction can be affected by both ecological and genetic factors (Ellstrand \& Roose, 1987; Eckert \& Barrett, 1993) and may be expected to determine the patterns of genetic diversity in population systems. Many monocotyledons have a propensity for clonal growth through rhizome extension. In particular, perennial aquatic plants have well-developed vegetative reproduction and often only rare sexual recruitment (Les, 1988) and may be expected to exhibit reduced levels of genetic diversity. However, hydrophiles appear to have reasonably high levels of diversity compared to flowering plant species generally, although they commonly have lower $P, H_{\mathrm{e}}$ and $H_{\mathrm{T}}$ but higher $G_{\mathrm{ST}}$ values. There are only a few studies directly comparable to this one among hydrophiles, with two on seagrass (Zostera marina, Laushman, 1993; Amphibolis antarctica, Waycott et al., 1996). The results presented here are for a widely distributed, hermaphrodite seagrass and show that $P$. australis is genetically diverse (allozyme analysis) like the monoecious $Z$. marina, whereas the dioecious $A$. antarctica is genetically uniform for allozyme and M13DNA fingerprint analysis. These observations suggest that the breeding system does not solely determine the extent of genetic diversity within seagrass species as has been previously suggested (Pettitt et al., 1981; Cox, 1993).

The highest level of genetic diversity in $P$. australis occurs within the region of greatest species richness where all eight described Australian species are known to coexist (Kirkman \& Walker, 1989). The environments along the southern coast of Australia, particularly in the western regions, are extremely heterogeneous and possess some of Australia's harshest coastline. This region is approximately that which joined the Australian land mass to Antarctica in Gondwanan times and the rift valley which formed is immediately off the Western Australian southern coast (Quilty, 1994). Prior to the rift valley forming, the main refugia for marine organisms would either have been in what are now more tropical waters in north-western Australia, or in eastern waters and south of Tasmania in what is now part of Antarctica. For Posidonia to move from either source into what is its present distribution would have required it to evolve mechanisms to cope with a wide range of environments from near-estuarine to open ocean conditions.

The absence of comparable selective pressures in the Mediterranean, where the other extant Posidonia occurs $(P$. oceanica), may help to explain the paucity of Posidonia species in the northern hemisphere. The hydrodynamic environment off the southern Australian coastline is characterized by strong currents and high wave energy which may have promoted strong selection pressures leading to the divergence of the $P$. ostenfeldii 'complex' and the $P$. australis 'complex' (see Cambridge \& Kuo, 1979 and Kuo \& Cambridge, 1984 for details on the two Australian Posidonia species complexes). In this scenario, $P$ australis might be one of a relatively rapidly evolving group in the process of increasing its range. This may explain the homogeneity observed in the north-western distribution extremes of this species (assuming range extension from the south) as discussed above. An alternative hypothesis for the genetic diversity in southern populations is that relatively recent hybridization has occurred between species in southern populations. It should be noted, however, that these species occur together for much of the western distribution and equivalent hybridization and diversity would be expected in these environments if this hypothesis were true. However, hybridization between east and west components of a widespread ancestral seagrass following separation of Antarctica and the Australian continent is another hypothesis which could explain both the genetic diversity within $P$. australis and the taxonomic diversity within the Australian representatives of this genus.

The $P$. australis 'complex' of three species shares many characteristics with the Mediterranean species $P$. oceanica, including morphology and ecological niches, and is less similar to the other Australian group, the $P$. ostenfeldii 'complex'. It is possible that the $P$. australis 'complex' and $P$. oceanica may be more similar to an ancestral type than either are to the $P$. ostenfeldii 'complex'. The species investigated in this study, $P$. australis, has the widest distribution of all the Australian Posidonia species. The differences in distribution of the Australian members of this genus may simply reflect the availability of suitable environments for each species. However, the extension of $P$. australis farther east than any other species may indicate its progenitor status. The evolution of these Posidonia species complexes is of considerable interest given the paucity of species diversity among the seagrasses as a whole, their ancient fossil record and apparent conservatism, with extant species identified in Eocene fossils (Larkum \& den Hartog, 1989). The observation presented here of elevated levels of genetic variation in $P$. australis coinciding with the region of greatest sympatry in the genus may well be meaningful, and warrants further investigation. 


\section{Acknowledgements}

The authors wish to acknowledge those who collected much of the material which made this study possible: L. Islip and P. Barnes (University NSW)-LMCQ; M. Wolterding (Sydney University)QUIB, HITW, PTHK; T. Evans, A. Boxshall (Melbourne University) and E. Young (Monash University)-CRNI; K. Edyvane and P. Preece (SARDI)-BLKP; A. Markey (Curtin University of Technology) and F. Webster (UWA)-LUKY, ROSS; M. Pennifold (UWA)-NCYC, MARM, 2PLB, FRMB; A. Brearley (UWA)-CPPN, MNKM, DENM, HRGB, GDIE, COSN, NCYC, WRNS; W. Lee-Long (Qld DPI)-THPB; G. Kendrick (CSIRO Fisheries)-NCYC; C. Sim (UWA)-NCYC, MARM; D. Clayton (WA Department of Fisheries)-BLGN. Thanks to T. Carruthers, J. Kennington, D. Les and J. Sampson for useful comments on the manuscript and to A. Calladine for assistance in preparation of the figures. This research was undertaken while MW held a University Research Studentship at The University of Western Australia.

\section{References}

ALbERTE, R. S., SUBA, G. K., PROCACCIN1, G., ZIMMERMAN, R. C. AND FAIN, S. R. 1994. Assessment of genetic diversity of seagrass populations using DNA fingerprinting: implications for population stability and management. Proc. Natl. Acad. Sci. U.S.A., 91, 1049-1053.

BARRETT, S. C. H. AND SHORE, J. S. 1989. Isozyme variation in colonizing plants. In: Soltis, D. E. and Soltis, P. S. (eds) Isozymes in Plant Biology, pp. 106-126. Dioscorides Press, Portland, OR.

BARRETT, S. C. H., ECKERT, C. G. AND HUSBAND, B. C. 1993. Evolutionary processes in aquatic plant populations. Aquat. Bot., 44, 105-145.

CAMBRIDGE, M. L. AND KUO, J. 1979. Two new species of seagrass from Australia, Posidonia sinuosa and $P$ angustifolia (Posidoniaceae). Aquat. Bot., 6, 307-328.

CAMBridge, M. L. AND McCOMB, A. J. 1984. The loss of seagrass in Cockburn Sound, Western Australia. I. The time course and magnitude of seagrass decline in relation to industrial development. Aquat. Bot., 21, 229-243.

COX, P. A. 1993. Water-pollinated plants. Sci. Am., 269(4), 50-56.

ECKERT, C. G. AND BARRETT, s. C. H. 1993. Clonal reproduction and patterns of genotypic diversity in Decodon verticillatus (Lythraceae). Am. J. Bot., 80, 1175-1182.

Ellstrand, N. C. AND RoOse, M. 1987. Patterns of genotypic diversity in clonal plant species. Am. J. Bot., 74, $123-131$.

HAMRICK, J. L. AND GODT, M. J. W. 1989. Allozyme diversity in plant species. In: Brown, A. H. D., Clegg, M. T., Kahler, A. L. and Weir, B. S. (eds) Plant Population
Genetics, Breeding and Genetic Resources, pp. 43-63. Sinauer Associates, Sunderland, MA.

KIRKMAN, H. 1985. Community structure in seagrasses in southern Western Australia. Aquat. Bot., 21, 363-375.

KIRKMAN, H. AND KUO, J. 1990. Pattern and process in southern Australian seagrasses. Aquat. Bot., 37, 367-382.

KIRKMAN, H. AND WALKER, D. I. 1989. Regional studiesWestern Australian seagrasses. In: Larkum, A. W. D., McComb, A. J. and Shepherd, S. A. (eds) Biology of Seagrasses: A Treatise on the Biology of Seagrasses with Special Reference to the Australian Region, pp. 157-181. Elsevier, Amsterdam.

KUO, J. 1982. Notes on the biology of Australian seagrasses. Proc. Linn. Soc. New South Wales, 106, 225-245.

KUO, J. AND CAMBRIDGE, M. L. 1984. A taxonomic study of the Posidonia ostenfeldii complex (Posidoniaceae) with description of four new Australian seagrasses. Aquat. Bot., 20, 267-295.

LARKUM, A. W. D. AND DEN haRTOG, C. 1989. Evolution and biogeography of seagrasses. In: Larkum, A. W. D., McComb, A. J. and Shepherd, S. A. (eds) Biology of the Seagrasses: A Treatise on the Biology of Seagrasses with Special Reference to the Australian Region, pp. 112-156. Elsevier, Amsterdam.

LAUSHMAN, R. H. 1993. Population genetics of hydrophilous angiosperms. Aquat. Bot., 44, 147-158.

LES, D. H. 1988. Breeding systems, population structure and evolution in hydrophylous angiosperms. Ann. Mo. Bot. Gard., 75, 819-835.

LES, D. H. 1991. Genetic diversity in the monoecious hydrophile Ceratophyllum (Ceratophyllaceae). Am. J. Bot., 78, 1070-1082.

LOKKER, C., SUSKO, D., LOVETT-DOUST, L. AND LOVETTDoust, J. 1994. Population genetic structure of Vallisneria americana, a dioecious clonal macrophyte. Am. J. Bot., 81, 1004-1012.

MCMILLAN, C. 1981. Morphological variation and isozymes under laboratory conditions in Cymodocea serrulata. Aquat. Bot., 10, 356-370.

Mcmillan, C. 1982. Isozymes in seagrasses. Aquat. Bot., 14, 231-243.

MCMILLAN, C. 1991. Isozyme patterning in marine spermatophytes. In: Triest, L. (ed.) Isozymes in Water Plants, pp. 193-200. National Botanic Garden of Belgium, Meise.

MORAN, G. F. AND HOPPER, S. H. 1983. Genetic diversity and the insular population structure of the rare granite rock species, Eucalyptus caesia Benth. Aust. J. Bot., 31, 161-172.

MURAWSKI, D. A. AND HAMRICK, J. L. 1990. Local genetic and clonal structure in the tropical terrestrial bromeliad, Aechmea magdalenae. Am. J. Bot., 77, 1201-1208.

NEI, M. 1978. Estimation of average heterozygosity and genetic distance from a small number of individuals. Genetics, 89, 583-590.

ORTH, R. J. AND MOORE, K. A. 1983. Chesapeake Bay: an 
unprecedented decline in submerged aquatic vegetation. Science, 222, 51-53.

PETTITT, J., DUCKER, S. AND KNOX, B. 1981. Submarine pollination. Sci. Am., 244(3), 92-101.

QuilTY, P. G. 1994. The background: 144 million years of Australian palaeoclimate and palaeogeography. In: Hill, R. S. (ed.) History of the Australian Vegetation: Cretaceous to Recent, pp. 14-43. Cambridge University Press, Cambridge.

RITLAND, K. 1989. Genetic differentiation, diversity, and inbreeding in the mountain monkeyflower (Mimulus caespitosus) of the Washington Cascades. Can. J. Bot., 67, 2017-2024.

ŠIDÁK, z. 1967. Rectangular confidence regions for the means of multivariate normal distributions. J. Am. Stat. Ass., 62, 626-633.

SWOFFORD, D. L. AND SELANDER, R. B. 1981. BIOSYS-1: a FORTRAN program for the comprehensive analysis of electrophoretic data in population genetics and systematics. J. Hered., 72, 281-283.

TRIEST, L. 1991. Enzyme polymorphism and its relationships to biological features in aquatic plants. In: Triest, L. (ed.) Isozymes in Water Plants, pp. 201-241. National Botanic Garden of Belgium, Meise.

WAIN, R. P., HALLER, W. T. AND MARTIN, D. F. 1985. Isozymes in studies of aquatic plants. J. Aquat. Pl. Manag., 23, 42-45.

WALKER, D. I. 1989. Regional studies-Seagrass in Shark
Bay, the foundations of an ecosystem. In: Larkum, A. W. D., McComb, A. J. and Shepherd, S. A. (eds) Biology of Seagrasses: A Treatise on the Biology of Seagrasses with Special Reference to the Australian Region, pp. 182-210. Elsevier, Amsterdam.

WALKER, D. I. AND McСомв, A. J. 1992. Seagrass degradation in Australian coastal waters. Mar. Poll. Bull., 25, 191-195.

WAYCOTT, M. 1995. Assessment of genetic variation and clonality in the seagrass Posidonia australis using RAPD and allozyme analysis. Mar. Ecol. Prog. Ser, 116, 289-295.

WAYCOTT, M. AND LES, D. H. 1996. An integrated approach to the evolutionary study of seagrasses. In: Kuo, J., Phillips, R. C., Walker, D. I. and Kirkman, H. (eds) Seagrass Biology: Proceedings of an International Workshop, Rottnest Island, Western Australia, 25-29 January 1996, pp. 71-78. Faculty of Science, The University of Western Australia, Perth.

WAYCOTT, M. AND SAMPSON, J. F. 1997. The mating system of an hydrophilous angiosperm Posidonia australis (Popsidoniaceae). Am. J. Bot. 84, 621-625.

WAYCOTT, M., WALKER, D. I. AND JAMES, S. H. 1996. Genetic uniformity in a dioecious seagrass, Amphibolis antarctica. Heredity. 76, 528-585.

WEST, R. 1990. Depth-related structural and morphological variations in an Australian Posidonia seagrass bed. Aquat. Bot., 36, 153-166. 